\title{
Metal Ion Release from Fine Particulate Matter Sampled in the Po Valley to an Aqueous Solution Mimicking Fog Water: Kinetics and Solubility
}

\author{
Valerio Di Marco, Andrea Tapparo, Denis Badocco, Sara D’Aronco, Paolo Pastore, \\ Chiara Giorio*
}

Department of Chemical Sciences, University of Padova, 35131 Padova, Italy

\begin{abstract}
Metals are among the key aerosol components exerting adverse health effects. Their toxic properties may vary depending on their chemical form and solubility, which can be affected by aqueous processing during aerosol atmospheric lifetime. In this work, fine particulate matter $\left(\mathrm{PM}_{2.5}\right)$ was collected in the city centre of Padua in the Po Valley (Italy), during a winter campaign. Part of the sampling filters were used to measure the kinetics by which metal ions and other elements can leach from $\mathrm{PM}_{2.5}$ to an aqueous solution mimicking fog water in the winter in temperate climate regions ( $\left.\mathrm{pH} 4.7,5^{\circ} \mathrm{C}\right)$. The leaching process was interpreted by a first order kinetics, and the fitting of the experimental data allowed to obtain the leaching kinetic constants and the equilibrium concentrations (i.e., at infinite time) for all elements. The remaining filter parts were mineralised, through two subsequent extraction steps, and the extracts were analysed by ICP-MS to gain the total elemental content of PM for a large number of elements. We found that elements can leach from PM with half times generally between 10-40 minutes, which is a timescale compatible with atmospheric aqueous processing during fog events. For instance, aluminium(III) in $\mathrm{PM}_{2.5}$ dissolved with an average $k=0.0185 \mathrm{~min}^{-1}$, and $t_{1 / 2}=37.5 \mathrm{~min}$. Nevertheless, a fraction of each element was immediately solubilised after contact with the extraction solution suggesting that metal ion solubilisation may already had started during particle lifetime in the atmosphere.
\end{abstract}

Keywords: Metals; $\mathrm{PM}_{2.5}$; Fog; Leaching kinetics; Urban air quality; ICP-MS.

\section{INTRODUCTION}

Particulate matter (PM), and especially its fine fraction $\left(\mathrm{PM}_{2.5}\right)$, existing in the atmosphere is considered to cause severe and different toxic effects on humans, including respiratory (Kowalska et al., 2019) and cardiovascular diseases (Du et al., 2019), nephrotoxicity (Hsu et al., 2005), diabetes (Lao et al., 2019), fetal distress in pregnant women (Liu et al., 2019), allergy (Dedele et al., 2019), autism (Kaufman et al., 2019), decreased fertility (Xia et al., 2019), and cancer (Santibáñez-Andrade et al., 2017). Eye irritation, dry throat, runny nose, sneezing, cough, tiredness, irritability, difficulty concentrating, headache, dizziness, and skin irritation are other less serious, indeed annoying side effects of human exposure to PM (Nezis et al., 2019).

Metal ions, non-metallic anions, and their inorganic derivatives (oxides, salts, etc.) are among the PM constituents (Brito et al., 2018; Meng et al., 2013; Popoola et al., 2018) which are considered to be co-responsible for PM toxicity, likely because of the oxidative stress which several chemical

\footnotetext{
${ }^{*}$ Corresponding author.

E-mail address: chiara.giorio@unipd.it
}

species may induce in cellular tissues (Meng et al., 2013; Liu et al., 2018; Yang et al., 2019). If PM is in contact with environmental or physiological solutions, the substances contained in the particles may be released, thus becoming bio-accessible and potentially toxic to living organisms and human tissues. For this reason, a very large number of papers have been or are being published in which the release of selected elements from PM to simulated physiological fluids was investigated (Benetello et al., 2018; Catalani et al., 2018; Dehghani et al., 2018; Gao et al., 2018; HernándezPellón et al., 2018; Huang et al., 2018; Kastury et al., 2018a, b; Nie et al., 2018; Pelfrêne and Douay, 2018; Wiseman et al., 2018; Berlinger et al., 2019; Du et al., 2019; HernándezPellón et al., 2019; Luo et al., 2019; Tang et al., 2019; Xing et al., 2019). For a list of older references see the review by Mukhtar and Limbeck (2013). In these literature studies, the elemental solubility at equilibrium has been obtained. Solubilities depended on the element, on the season, on which species were loaded on the particle, on the distance of the sampling site from the element source, on the PM size, on the solution $\mathrm{pH}$, and on pre-existing components in aqueous solution (Benetello et al., 2018; Dehghani et al., 2018; Gao et al., 2018, Hernández-Pellón et al., 2018; Kastury et al., 2018a, b; Pelfrêne and Douay, 2018; Hernández-Pellón et al., 2019; Xie et al., 2019; Xing et al., 2019). 
Another information which has been sought in the literature, even if much less often than equilibrium solubility, was the kinetics of the solubilisation process (Desboeufs et al., 1999; Desboeufs et al., 2005; Hsu et al., 2005; Joshi et al., 2009; Armiento et al., 2013; Huang et al., 2016; Dufka and Dočekal, 2018). The rate by which a given element is released from the PM can be as relevant as the solubility at equilibrium, because this data would allow to model also the timing of the releasing process, especially when the contact between PM and aqueous phase does not last for long times. Very different kinetic results were reported: for example, leaching was found to be complete in timescales spanning from few minutes to 2 h (e.g., Desboeufs et al. (1999, 2005), Hsu et al. (2005)), but other authors found that some elements reached equilibrium only after several hours (Joshi et al., 2009; Huang et al., 2016) or even few days (Armiento et al., 2013). The release kinetics was shown to be affected by solution pH (Desboeufs et al., 1999, 2005) and in general it is expected to depend on the same factors affecting equilibrium solubility, so that no general conclusions can be drawn about any element. Indeed, kinetic data reported in the literature are still scarce, and studies on this matter should lead to a better knowledge of the complex phenomena occurring when PM is in contact with an aqueous phase.

In this paper, the kinetics of the release of metal ions from $\mathrm{PM}_{2.5}$ samples into a simulated fog water was investigated in order to study how the aqueous processing affects the solubility of the elements during aerosol lifetime in the atmosphere. The PM was collected during a winter season in the Po Valley (northern Italy), which is characterised by a significant air pollution during winter because it is an intensely urbanised area surrounded by complex orography. To the best of our knowledge, for the Po Valley no kinetic study of elemental release from PM has been hitherto performed. Whereas most of the above mentioned literature focused on kinetic measurements in physiological fluids or marine water, leaching experiments were here performed in an aqueous solution (with $\mathrm{H}_{2} \mathrm{SO}_{4}$ and $\mathrm{HNO}_{3}$ at $\mathrm{pH}=4.7$ ) and at a temperature $\left(5^{\circ} \mathrm{C}\right)$ which better resemble the typical winter environmental conditions of humid, foggy or rainy days in temperate climate regions including the Po Valley. The study was extended to as many elements as possible, and solubility and PM total element content were obtained as well. The latter was performed by using a two-step ICPMS-based analytical procedure with the aim to detect also elements present at very low concentration.

\section{EXPERIMENTAL}

\section{Chemicals}

The reagents used were hydrochloric acid (Aldrich 37\%), sulphuric acid (95-97\%, Fluka), nitric acid (68.5-69.5\%, Aristar for trace analysis, VWR), zinc acetate dihydrate (99.5\% min, Riedel de Haën), methanol (99.9\%, VWR), EDTA disodic salt (Carlo Erba), ammonium nitrate ( $99 \%$ min, Merck), ammonia (30-33\%, Sigma Aldrich), eriochrome black T (EBT, Sigma Aldrich), sodium chloride (99.5\% min, Analar Normapur), Rhenium standard for ICP (1001 $\pm 5 \mathrm{mg} \mathrm{L}^{-1}, 2 \%$ $\mathrm{HNO}_{3}$, Sigma Aldrich), Germanium standard for ICP (1005 $\pm 2 \mathrm{mg} \mathrm{L}{ }^{-1}, 2 \% \mathrm{HNO}_{3}$, Sigma Aldrich), Terbium standard for ICP (1002 $\pm 5 \mathrm{mg} \mathrm{L}{ }^{-1}, 2 \% \mathrm{HNO}_{3}$, Sigma Aldrich), calibrating standard solution CCS-5 for ICP (100.00 \pm $0.70 \mu \mathrm{g} \mathrm{mL}^{-1}$ of B, Ge, Hf, Mo, Nb, P, Re, S, Sb, Si, Sn, Ta, $\mathrm{Ti}, \mathrm{W}, \mathrm{Zr}, 1.2 \%$ (v/v) $\mathrm{HF}+7.43 \%$ (v/v) $\mathrm{HNO}_{3}$, Inorganic Ventures), and calibrating standard solution IV-ICPMS-71A $\left(10 \pm 0.08 \mu \mathrm{g} \mathrm{mL}^{-1}\right.$ of Ag, Al, As, B, Ba, Be, Ca, Cd, Ce, $\mathrm{Co}, \mathrm{Cr}, \mathrm{Cs}, \mathrm{Cu}$, Dy, Er, Eu, Fe, Ga, Gd, Ho, K, La, Lu, Mg, $\mathrm{Mn}, \mathrm{Na}, \mathrm{Nd}, \mathrm{Ni}, \mathrm{P}, \mathrm{Pb}, \mathrm{Pr}, \mathrm{Rb}, \mathrm{S}, \mathrm{Se}, \mathrm{Sm}, \mathrm{Sr}, \mathrm{Th}, \mathrm{Tl}, \mathrm{Tm}, \mathrm{U}$, $\mathrm{V}, \mathrm{Yb}, \mathrm{Zn}$, Inorganic Ventures). $\mathrm{HCl}$ was distilled to $6 \mathrm{M}$ prior use. All solutions were prepared and diluted using ultrapure water obtained with a Millipore Plus System (Milan, Italy, resistivity $18.2 \Omega \mathrm{cm}^{-1}$ ).

\section{Instrumentation and Procedure}

The teflon filters (PALL, fiberfilm, Ø $47 \mathrm{~mm}, 2.0 \mu \mathrm{m}$ pore size) were conditioned for $24 \mathrm{~h}$ inside a Q-Box3 Momo Line box at $20 \pm 1{ }^{\circ} \mathrm{C}$ and at $50 \pm 5 \%$ relative humidity, and then they were loaded on a Aircube He pump equipped with a $\mathrm{PM}_{2.5}$ certified selector (CEN standard method UNI-EN 14907). $\mathrm{PM}_{2.5}$ sampling was performed on each filter for $24 \mathrm{~h}$ (from 9am to 9am of the following day) at a constant flow rate of $2.3 \mathrm{~m}^{3} \mathrm{~h}^{-1}$. The sampling campaign was performed from the $22^{\text {th }}$ January to the $21^{\text {st }}$ February 2018 , and 18 filters have been collected. The exact sampling days are reported in Table S1 (Supporting information). Sampling (outdoor) location was the sixth floor of the Department of Chemical Sciences, which is close to the city centre of Padua (Italy). Additional details about the sampling facility can be found elsewhere (Giorio et al., 2013). The amounts of $\mathrm{PM}_{2.5}$ collected in all sampling days are reported in Table S1; these values were obtained from the Agency for Environmental Protection in the Veneto Region (ARPAV, http://www.arpa. veneto.it/), which performs daily measurements to evaluate air quality in Padua and in other cities. Among all ARPAV sampling sites, results from "PD-Mandria" were considered, as this site is the closest to the Department of Chemical Sciences. The other environmental parameters measured by ARPAV during the same sampling days (pollutant concentrations and weather-related values) are reported in Table S2.

At the end of the sampling time, each filter was cut into two parts (3/4 and 1/4). The first part was used to perform kinetic and equilibrium solubility measurements, and the second one was used to determine the elemental total content. After PM sampling and before subsequent measurements, filters were stored in the refrigerator $\left(-18^{\circ} \mathrm{C}\right)$.

\section{Kinetic and Equilibrium Solubility Measurements}

A glass filter holder was built to perform kinetic/solubility measurements (Fig. S1 in the Supporting Information). It comprises a $c a .15 \mathrm{~cm}$ long haft, and a $c a .5 \mathrm{~cm}$ wide and $1 \mathrm{~cm}$ tall cylinder. The lower part of the cylinder is folded to allow the insertion of the filter and avoid its accidental removal once the experiment is started. The lateral part of the cylinder has eight holes to allow the leaching substances to quickly dissolve within the bulk solution. The filter holder was put in the fridge $\left(4^{\circ} \mathrm{C}\right)$ before use to assure that it would not heat the $5^{\circ} \mathrm{C}$ solution once immersed.

The solvent used for the leaching experiments was a 
$5.3 \cdot 10^{-6} \mathrm{M} \mathrm{H}_{2} \mathrm{SO}_{4}$ solution containing also $10 \mu \mathrm{g} \mathrm{L}^{-1}$ of internal standards for ICP-MS $\left({ }^{72} \mathrm{Ge},{ }^{159} \mathrm{~Tb},{ }^{183} \mathrm{Re}\right)$ and 9.4 $10^{-6} \mathrm{M} \mathrm{HNO}_{3}$, and it had a computed $\mathrm{pH}$ equal to 4.7. For each experiment, the solvent $(100 \mathrm{~mL})$ was loaded into a water-jacketed cell (Metrohm) having a volume capacity of $150 \mathrm{~mL}$. A constant stirring (200 rpm) and temperature $\left(5.0 \pm 0.1^{\circ} \mathrm{C}\right)$ were set and maintained by a magnetic stirrer and a Haake F3 cryostat, respectively. A 3/4 piece of filter was loaded in the holder and inserted in the cell: this moment represented time $=0$ for kinetic experiments. Twenty-two samples withdrawals $(3 \mathrm{~mL}$ each, representing the minimum volume requirement for ICP-MS analysis) were performed at the following times $(\mathrm{min}): 0,2,4,6,8,10,12,14,16,18$, $20,22,24,26,28,30,45,60,90,120,240,360$. The starting volume was chosen to assure that the filter remained immersed in the solvent till the last withdrawal was performed. Each withdrawn sample was transferred to $15 \mathrm{~mL}$ Falcon tubes, previously washed with $c a$. $0.01 \mathrm{M} \mathrm{HCl}(2 \mathrm{~mL})$, rinsed with water and left to dry. Tubes were added with conc. $\mathrm{HNO}_{3}$ $(150 \mu \mathrm{L})$ to obtain a matrix $\left(3.45 \% \mathrm{w} / \mathrm{w} \mathrm{HNO}_{3}\right)$ which was similar to the standard solutions and best suitable for the ICP-MS analysis. The tubes were closed and kept in the fridge $\left(T=4^{\circ} \mathrm{C}\right)$ until analysis via ICP-MS. The cell and the filter holder were washed with conc. $\mathrm{HNO}_{3}$ and then rinsed with water after each experiment.

A check test was performed to confirm that the leaching elements were able to diffuse enough from the filter holder, thus avoiding erroneous results due to inhomogeneous solutions. Test (blank) filters loaded with a ca. $1 \mathrm{M}$ zinc acetate solution (few droplets) prepared in methanol and left to dry under vacuum for some hours at $100{ }^{\circ} \mathrm{C}$ were used. 10 sample withdrawals $(6 \mathrm{~mL}$ each) were performed every $1 \mathrm{~min}$ from the cell. Each test sample was transferred to $15 \mathrm{~mL}$ Falcon tubes, added with ammonium/ammonia buffer $(1 \mathrm{~mL})$ at $\mathrm{pH} 10\left(0.509 \mathrm{~g} \mathrm{NH}_{4} \mathrm{NO}_{3}+2.070 \mathrm{~g} \mathrm{NH}_{3}\right.$ dissolved in $5 \mathrm{~mL}$ water) and with the indicator $(c a .0 .1 \mathrm{~g}$, taken from a mixture of $0.05 \mathrm{~g} \mathrm{EBT}+10 \mathrm{~g} \mathrm{NaCl}$ ) and titrated with $0.02 \mathrm{M}$ EDTA. The equivalence volume of EDTA became identical for all test solutions starting from the 2 min withdrawal, which therefore was considered to be both the homogenisation timing and the time resolution of the kinetic measurements.

Blanks were collected after $c a .1 \mathrm{~h}$ stirring from tests in which $a$ ) only the solvent, $b$ ) the solvent and the filter holder, $c$ ) the solvent, the filter holder and a conditioned filter, were inserted in the cell. These blanks were then analysed by ICPMS. Other two blanks containing either $0.01 \mathrm{M} \mathrm{HCl}$ or $150 \mu \mathrm{L} \mathrm{HNO}_{3}$ in $3 \mathrm{~mL}$ water were also analysed. These blanks evidenced significant contaminations for a few elements due to the procedure (see below).

\section{Measurements of Total Elemental Content}

For each of the 18 filters ( $1 / 4$ pieces), the total elemental content was determined by two subsequent analytical steps. In the first step, each filter was put in a $15 \mathrm{~mL}$ Falcon tube and added with $3.45 \% \mathrm{w} / \mathrm{w} \mathrm{HNO}_{3}(3 \mathrm{~mL})$ containing also an internal standard for ICP-MS $\left({ }^{159} \mathrm{~Tb} 10 \mu \mathrm{g} \mathrm{L} \mathrm{L}^{-1}\right)$. Tubes were closed and heated at bain-marie $\left(100^{\circ} \mathrm{C}\right)$ for $2 \mathrm{~h}$. The solutions obtained were removed from the tubes, added with the three water aliquots ( $100 \mu \mathrm{L}$ each) previously used to rinse the filters, and they were subjected to the ICP-MS analysis. In the second step, $3 \mathrm{~mL}$ of conc. $\mathrm{HNO}_{3}$ were added to each tube containing a filter, then the tube was closed and heated at bain-marie $\left(100^{\circ} \mathrm{C}\right)$ for $1 \mathrm{~h}$. At the end, samples were diluted with water containing also an internal standard for ICP-MS $\left({ }^{72} \mathrm{Ge} 10 \mu \mathrm{g} \mathrm{L}^{-1}\right)$ to obtain $3.45 \%$ w/w $\mathrm{HNO}_{3}$ solutions which were subjected to another ICP-MS analysis.

\section{ICP-MS Analysis}

The elemental analyser was an ICP-MS Agilent series 7700x (Agilent Technologies International Japan, Ltd., Tokyo, Japan). The instrumental operating conditions were as follows: radiofrequency power $1550 \mathrm{~W}$, RF matching 1.8 $\mathrm{V}$, plasma gas (Ar) flow rate $15 \mathrm{~L} \mathrm{~min}^{-1}$, carrier gas (Ar) flow rate $1.05 \mathrm{~L} \mathrm{~min}^{-1}$, He gas flow rate $4.3 \mathrm{~mL} \mathrm{~min}^{-1}$, $\mathrm{CeO}^{+} / \mathrm{Ce}^{+}=0.90 \%$, nebuliser type: microflow PFA, spray chamber type: Scott Double Pass at $2^{\circ} \mathrm{C}$, sample introduction speed $0.1 \mathrm{~mL} \mathrm{~min}^{-1}$, internal diameter of nickel cone $1.0 \mathrm{~mm}$, internal diameter of skimmer cone $0.5 \mathrm{~mm}$, sampling depth $8.5 \mathrm{~mm}$, dwell time $/$ mass $=100$. The isotopes ${ }^{72} \mathrm{Ge},{ }^{159} \mathrm{~Tb}$, and ${ }^{183} \mathrm{Re}$ were used as internal standards to monitor the instrumental drift. Quantification has been performed by means of the external calibration method. Overall 437 analyses (396 for kinetics/solubility +36 for total elemental content +5 blanks) were performed.

It was possible to determine concentration values for the following elements, either only for the total elemental content, or also for the kinetic/solubility measurements: Al, As, Ba, Ca, Cd, Cr, Cu, Fe, K, Mg, Mn, Mo, Na, Ni, Pb, Rb, $\mathrm{Sb}, \mathrm{Sr}, \mathrm{V}, \mathrm{W}$, and $\mathrm{Zn}$. The instrumental detection limit (LOD) and quantification limit (LOQ) for each element were determined as described previously (Badocco et al., 2015; Roverso et al., 2015), and they are reported in Table S3. Values for B, Lu, P, Si were excluded due to anomalies in the calibration graphs (due to high LODs in the case of $\mathrm{B}, \mathrm{P}$ and $\mathrm{Si}$ ), whereas results for $\mathrm{Cl}$ and $\mathrm{Hg}$ were discarded as they showed strong memory effects. The signals of $\mathrm{Au}, \mathrm{Be}$, Br, Ce, Co, Cs, Dy, Er, Eu, Ga, Gd, Hf, Ho, I, Ir, La, Li, Nb, Nd, Pd, Pr, Pt, Ru, Se, Sm, Ta, Te, Th, Tl, Tm, U, Y, Yb, detected in the samples resulted practically identical to those detected in the blanks, therefore also these elements were not further considered. $\mathrm{Ca}, \mathrm{Mg}, \mathrm{Na}$, and $\mathrm{Ni}$ were not determined due to contamination of blank filters.

The concentration values (in $\mu \mathrm{g} \mathrm{L}^{-1}$ ) obtained by ICP-MS from kinetic/solubility measurements were corrected to the values which would have been obtained if no volume withdrawals were performed from the cell. The corrected concentration corresponding to the $x^{\text {th }}$ withdrawal $\left(c_{x}\right)$ was obtained by the formula:

$c_{x}=\frac{c^{\prime}{ }_{x} V_{x}+\sum_{i=1}^{x}\left[c^{\prime}{ }_{i}\left(V_{i}-V_{i+1}\right)\right]}{V_{0}}$

where $V_{0}$ is the starting volume $(0.1 \mathrm{~L}), \quad c_{i}^{\prime}$ is the experimental concentration obtained from the ICP-MS analysis after the $i^{\text {th }}$ volume withdrawal $(1 \leq i \leq x)$, and $V_{i}$ is the volume of solution after the $i^{\text {th }}$ withdrawal $\left(V_{i}-V_{i+1}=\right.$ 
$\left.3 \cdot 10^{-3} \mathrm{~L}\right)$. The first term of the numerator is the mass of element experimentally contained in the solution, and the summation represents the total amount of element which has been removed to perform all measurements before the $x^{\text {th }}$ one.

Concentrations in air $\left(\mathrm{ng} \mathrm{m}^{-3}\right)$ for each element in each individual sample were obtained by calculating the mass (ng) of each element from the concentration in the extracts adjusted for the portion of filter analysed and dividing it by the volume of sampled air $\left(\mathrm{m}^{3}\right)$. The soluble concentrations at $t_{\infty}$ were estimated by averaging values obtained at $\mathrm{t}>60 \mathrm{~min}$ in the kinetic experiments, when a plateau concentration was reached. The soluble fraction was then calculated by dividing the soluble concentration at $t_{\infty}$ by the total concentration of the element in each individual sample.

\section{Statistical Analysis}

Correlation tests have been performed in R (v 3.4.1) by using the Spearman method (Field et al., 2012). A correlation was considered significant if the computed $p$-value was below 0.05 . Final data reported in the tables were checked for outliers using the Tukey's rule.

\section{RESULTS AND DISCUSSION}

Some of the concentration-time profiles obtained during the kinetic experiments are shown in Fig. 1. Generally, the elemental concentrations clearly increased over time, indicating that a leaching was occurring. According to our data, leaching appeared generally to stop after 1-2 hours; data was prudentially collected till $6 \mathrm{~h}$, and in few cases (in particular for Sb, see Fig. 1) some further leaching was observed. Data collection was in any case ended after $6 \mathrm{~h}$. For some of the analysed elements, observed concentrations were below the LOQ and no kinetic data could be obtained.

The occurrence of a time-dependent leaching was investigated for each element in each sample by performing Spearman correlation tests: if $p$-value was below 0.05 , it meant that the concentration for the given element in the examined sample was varying significantly over time. Spearman correlation, better than the more common Pearson one, is robust against outliers and is able to show correlations also when the variables are not related linearly (Field et al., 2012), as it is the case in this work. Results from the Spearman tests are given in Fig. 2, which shows for each element which samples gave $p$-values below 0.05 , which samples gave $p$-values above 0.05 , and which samples had concentration below the LOQ.

Even for elements which showed marked kinetic behaviours, kinetically non-significant concentration changes ( $p$-value $\geq 0.05$ ) were determined in a few samples. This result can be partly explained by noisy data, which, in some cases, has probably caused $p$-values being larger than 0.05 .
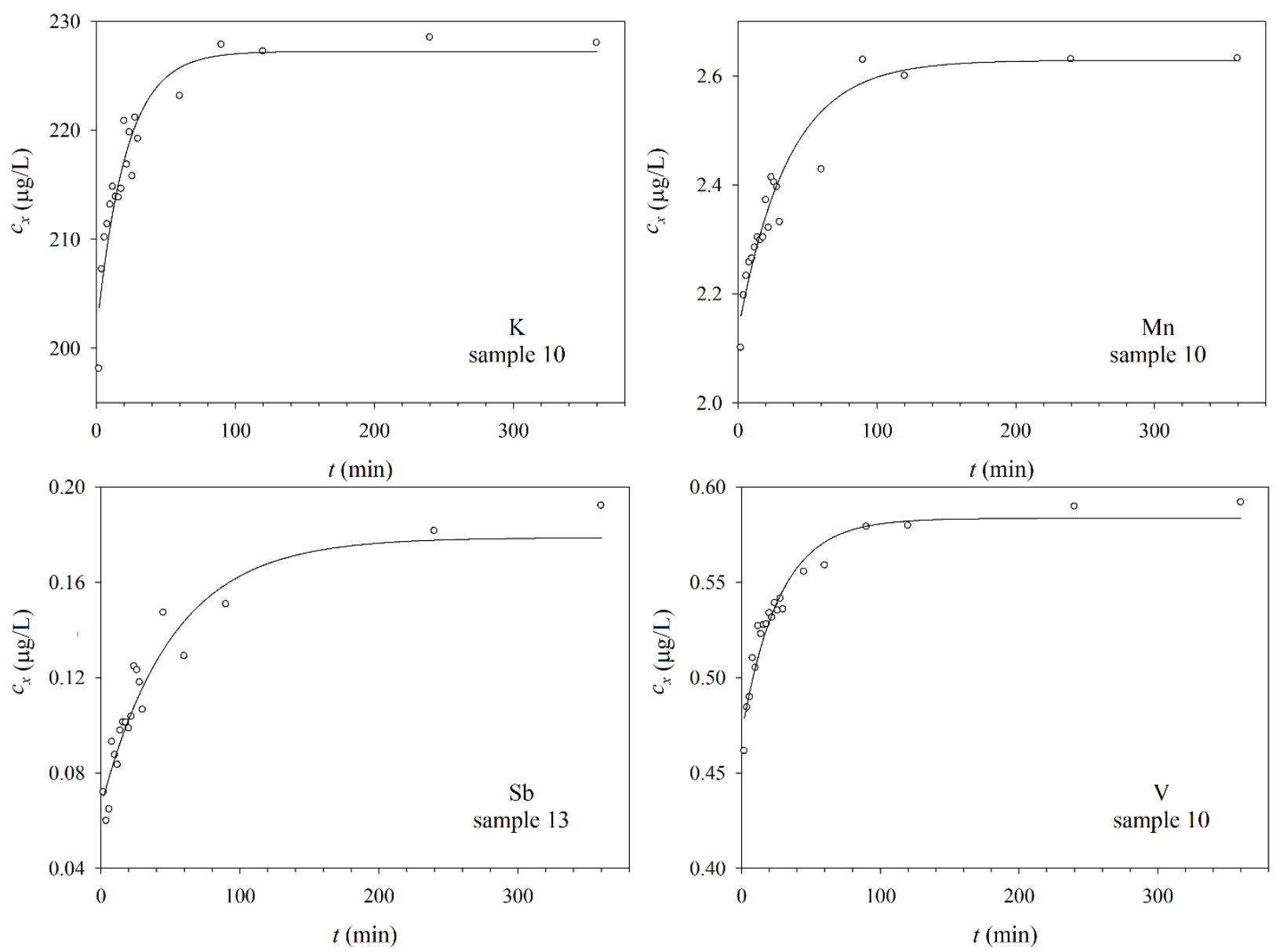

Fig. 1. Experimental points and fitting lines (Eq. (3)) obtained in the kinetic measurements of elemental release from $\mathrm{PM}_{2.5}$. 


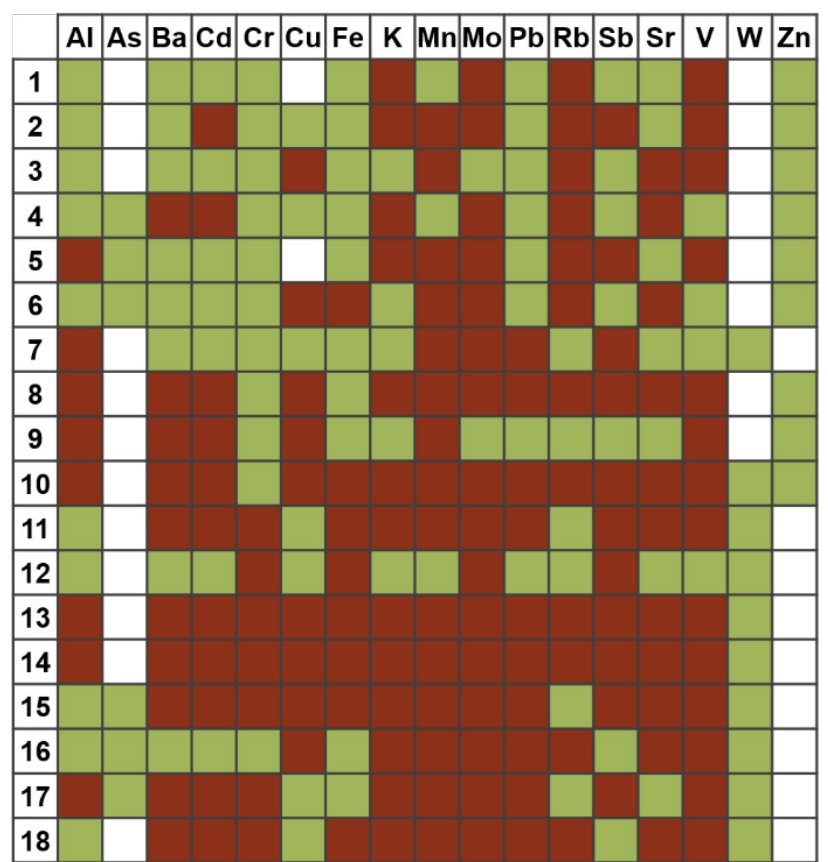

Fig. 2. Diagram showing in which of the 18 samples element concentration was significantly ( $p$-value $<0.05)$ varying over time according to the Spearman test (brown), nonsignificantly ( $p$-value $\geq 0.05$ ) varying over time (green), or below LOQ (white).

It was decided to evaluate the kinetics for elements for which the concentration changes were significant in at least six samples.

Unexpected results were obtained for $\mathrm{Pb}$, for which concentrations were decreasing over time rather than increasing. To the best of our knowledge, this behaviour was never described in literature. As a tentative explanation, it can be hypothesised that $\mathrm{Pb}$ was very rapidly released from PM once in contact with an aqueous solution, and then it reacted with other species released from the PM itself or contained in the solvent, forming insoluble products which cannot be detected by the ICP-MS analysis. For example, $\mathrm{Pb}^{2+}$ can form insoluble precipitates with several anions, such as halogenides, cyanide, sulphate, etc.

The kinetic data obtained during the experiments can be fitted by a suitable equation. Some of the previous papers regarding leaching kinetics from PM did not treat their data, but they only verified the leaching times (Hsu et al., 2005; Armiento et al., 2013) or showed the applicability of a new method (diffusive gradients in thin film) for the analysis of PM (Dufka and Dočekal, 2018). In the other papers, it was considered that the leaching rate determining step was the solubilisation from the PM surface, so that a first order kinetic law should apply (Desboeufs et al., 1999; Joshi et al., 2009; Huang et al., 2016). The same hypothesis was made here, and the following differential equation was considered:

$$
\frac{d c_{x}}{d t}=k^{\prime}\left(s_{0}-r c_{x}\right)
$$

where $k^{\prime}$ is the first order kinetic constant, and the term in brackets represents the concentration of the given element on the PM surface at time $t$, which is equal to the surface concentration at $t=0\left(s_{0}\right)$ minus the dissolved amount $r c_{x}$ (where $r$ is a constant which relates surface and solution concentrations). By solving Eq. (2), the integral equation for the first order kinetics is obtained:

$c_{x}=c_{e}-A e^{-k t}$

where $A$ is the pre-exponential factor, $k$ is the kinetic constant $\left(k=r k^{\prime}\right)$, and $c_{\mathrm{e}}$ (defined as $\left.s / r\right)$ represents the solution concentration at equilibrium $(t=\infty)$, i.e., the element solubility at the employed conditions $\left(\mathrm{pH}=4.7, T=5^{\circ} \mathrm{C}\right)$. For a summarising purpose, average values of $k$ and $t_{1 / 2}$ have been computed for each element, and they have been weighted using the uncertainty values obtained by the fitting procedure. Weighted average values of $k$, and $t_{1 / 2}$ obtained for each element are reported in Table 1 while $k$ values for each individual sample are reported in Table S4.

All kinetic constants obtained in this work were of the order of $10^{-2} \mathrm{~min}$. Values for $\mathrm{Al}, \mathrm{Cr}$, Sr were slightly lower than for other elements, whereas values for $\mathrm{Cd}$ and $\mathrm{Rb}$ were slightly larger. $\mathrm{Al}, \mathrm{Cr}, \mathrm{Sr}$ are of crustal origin, whereas $\mathrm{Cd}$ and $\mathrm{Rb}$ are of industrial and vehicular origin, and it is reasonable that the former elements have a more stable crystalline network, making these elements more refractory to solubilisation compared with $\mathrm{Cd}$ and $\mathrm{Rb}$. This consideration explained solubility values obtained by Desboeufs et al. (2005), and might explain also the present kinetic results. Joshi et al. (2009) analysed PM samples collected in Singapore, and they obtained $k$ values $\left(\mathrm{min}^{-1}\right)$ in the range $0.2-0.6 \cdot 10^{-2}$ for $\mathrm{Al}, 0.3-3 \cdot 10^{-2}$ for $\mathrm{Cr}, 0.1-2 \cdot 10^{-2}$ for $\mathrm{Fe}, 0.3-6 \cdot 10^{-2}$ for $\mathrm{Mn}$, and $0.3-4 \cdot 10^{-2}$ for $\mathrm{V}$, which were in line with those obtained in this work. However, some elements were reported to have a leaching kinetics only in the present work, and others only in the work of Joshi et al, likely because of the different PM origin and different leaching solutions used. To the best of our knowledge, no other papers reported kinetic constants for PM leaching (for example, Desboeufs et al. (2005) reported only leaching rates).

Desboeufs et al. $(2005,1999)$ found that the dissolution rate of some elements followed a two-step process. During the first step the particle was hydrated, the element release was very quick (with a timing of a few minutes), and the rate increased with time. During the second step the rate decreased with time. For some other elements, conversely, only one step (the second one) was observed. Other studies observed only a single leaching step for all elements, and the rate was decreasing with time (Joshi et al., 2009; Armiento et al., 2013). It is worth noting that in the present experiments the values of $c_{x}$ at time $=0$ were generally larger than zero (Fig. 1), thus indicating that part of the elements has leached to the solution during the very few instants after the PM-water contact. Furthermore, Eq. (3) was generally not able to fit experimental data well unless the concentration values at time zero were excluded from the fitting set. These findings suggest that also in the present case two steps took place during the leaching experiments, but the first step was very 
Table 1. Weighted averages of $k$, and $t_{1 / 2}$ obtained for each element and all samples $(N)$ for which a marked kinetic behaviour was observed. The corresponding standard deviations, computed for the weighted means, are given in brackets.

\begin{tabular}{llll}
\hline element & $k\left(\mathrm{~min}^{-1}\right)$ & $t_{1 / 2}(\min )$ & $N$ \\
\hline $\mathrm{Al}$ & $0.0185(0.0036)$ & $37.5(7.3)$ & 8 \\
$\mathrm{As}$ & - & - & - \\
$\mathrm{Ba}$ & $0.0192(0.0019)$ & $36.1(3.6)$ & 10 \\
$\mathrm{Cd}$ & $0.0271(0.0029)$ & $25.6(2.7)$ & 7 \\
$\mathrm{Cr}$ & $0.0079(0.0016)$ & $88(18)$ & 9 \\
$\mathrm{Cu}$ & $0.0135(0.0023)$ & $51.3(8.7)$ & 8 \\
$\mathrm{Fe}$ & $0.0143(0.0025)$ & $48.5(8.4)$ & 13 \\
$\mathrm{~K}$ & $0.0478(0.0032)$ & $14.5(1.0)$ & 15 \\
$\mathrm{Mn}$ & $0.0247(0.0020)$ & $28.1(2.2)$ & 16 \\
$\mathrm{Mo}$ & $0.0226(0.0015)$ & $30.7(2.0)$ & 10 \\
$\mathrm{~Pb}$ & - & - & 12 \\
$\mathrm{Rb}$ & $0.0463(0.0050)$ & $15.0(1.6)$ & 11 \\
$\mathrm{Sb}$ & $0.0140(0.0011)$ & $49.5(4.0)$ & 11 \\
$\mathrm{Sr}$ & $0.0098(0.0016)$ & $71(12)$ & 14 \\
$\mathrm{~V}$ & $0.0218(0.0019)$ & $31.7(2.7)$ & - \\
$\mathrm{W}$ & - & - & - \\
$\mathrm{Zn}$ & - & - & \\
\hline
\end{tabular}

quick and comparable to the time resolution of the kinetic measurements ( $c a .2 \mathrm{~min}$ ); therefore, it could not be detected. The fact that a fraction of the elements is released immediately after contact with water may indicate that an aqueous phase processing of the particles had already happened during their atmospheric lifetime either because they were in a deliquescent state or because of the presence of fog.

Other than $c_{\mathrm{e}}$, the total elemental concentration which can dissolve from the PM $\left(c_{T}\right)$ was determined for each sample. These measurements have been performed by subjecting the filters to two subsequent digestions: a first one, employing hot diluted $(3.45 \% \mathrm{w} / \mathrm{w}) \mathrm{HNO}_{3}$, and a second one in which hot concentrated $\mathrm{HNO}_{3}$ was used. The latter condition represented a strong acidic and oxidising digestion which is expected to solubilise all elemental species present in PM, whereas the former was a milder procedure which might be non-exhaustive. A milder digestion was performed because the samples obtained in this way did not need any dilution prior to the ICP-MS analysis, thus elements at very low concentrations may be better detected than after a hot acid digestion that requires dilution to $3.45 \% \mathrm{HNO}_{3}$ before analysis. The concentrations obtained after a mild digestion are shown in Table S5. Values obtained after the two successive procedures, which represent total concentration, $c_{\mathrm{T}}$, are reported in Table 2 .

The comparison between Tables S5 and 2 indicates that most elements solubilised in a complete manner $(>90 \%)$ also in hot diluted $\mathrm{HNO}_{3}$ (mild digestion). This solvent thus simultaneously allowed to quantitatively solubilise most elements from PM and to measure concentration values close to the LOD. Only Al, and only in some samples, was not completely solubilised in diluted $\mathrm{HNO}_{3}$; the determination of its total amount in PM required a second analytical step with a digestion in concentrated $\mathrm{HNO}_{3}$.

Median values of soluble metal ions and total element content are reported in Table 3. Benetello et al. (2018) analysed the $\mathrm{PM}_{2.5}$ of Padua sampled in the year 2012-2013: results are given as well in Table 3 for comparison. Differences between values from Benetello et al. (2018) and those of the present study were very modest. Also results of Armiento et al. (2013) were taken into account for comparison; they analysed the $\mathrm{PM}_{2.5}$ fraction collected in another Italian city (Rome) in the year 2011-2012. These values, shown in Table 3, were even more similar to ours than those of Benetello et al. (2018). It is also worth noting that in the present work the analysis and detection of more PM elements, than in cited papers, was possible thanks to the two-step procedure developed for the ICP-MS analysis of the total elemental content.

The soluble fractions of the elements which can dissolve at $\mathrm{pH}=4.7$ and $T=5^{\circ} \mathrm{C}$ represent the fractions becoming potentially bio-accessible. Fractions ranged between $\mathrm{ca}$. 10$20 \%$ for $\mathrm{Cu}, \mathrm{Fe}, \mathrm{Sb}$, up to $80-100 \%$ for alkali and alkaline earth metal ions, $\mathrm{Cd}$, and $\mathrm{Zn}$ (Table 3).

\section{Conclusions and Perspectives}

In this work, leaching kinetics and equilibrium solubility were evaluated for elements leaching from PM to an environmentally relevant aqueous solution mimicking fog water. A two-step analytical procedure allowed also to analyse the total content of a larger number of elements than those generally detected in the literature. Equilibrium solubility and total elemental content can allow to evaluate the fraction of each element which can solubilise from the PM. The results of our kinetic experiments showed also that a fraction of the elements was immediately released in the aqueous solution (at time $=0$ ), and a slower release following a first-order kinetic took place simultaneously. Kinetic measurements gave constants of the order of $10^{-2} \mathrm{~min}^{-1}$, from which it is calculated that elements can leach from PM with half times of 10-40 minutes. This timing is compatible with the atmospheric lifetime of clouds and fogs (Xue et al., 2006; Ervens and Volkamer, 2010; Maalick et al., 2016) and it should be taken into account if the leaching of elements 
Table 2. Values of total concentration, $c_{\mathrm{T}}\left(\mathrm{ng} \mathrm{m}^{-3}\right)$, obtained for each element in all 18 samples. Uncertainties were of the order of $5 \%$.

\begin{tabular}{|c|c|c|c|c|c|c|c|c|c|c|c|c|c|c|c|c|c|c|}
\hline & 1 & 2 & 3 & 4 & 5 & 6 & 7 & 8 & 9 & 10 & 11 & 12 & 13 & 14 & 15 & 16 & 17 & 18 \\
\hline $\mathrm{Al}$ & 107 & & & & & & & $1375^{*}$ & & & & & & 32.0 & 47.6 & & & \\
\hline & & & & & & & & & & & & & & & & & & \\
\hline & & & & & & & & & & & & & & & & & & \\
\hline & & & & & & & & & & & & & & & & & & \\
\hline & & & 3.99 & & & & & & & & & & & & & & & \\
\hline$u$ & & & 2 & & & & & & & & & & & & & & & .78 \\
\hline & & & & & & & & & & & & & & & & & & \\
\hline & & & & & & & & & & & & & & & 4 & & & 255 \\
\hline & & & & & & & & & & & & & & & & & & \\
\hline & & & 480 & & & & & & & & & & & & & & & 0.5 \\
\hline & & & & & & & & & & & & & & & & & & \\
\hline & & & & & & & & & & & & & & & 8 & & & 67 \\
\hline $\mathrm{Sb}$ & & & & & & & & & & & & & & & & & & \\
\hline & & & & & & & & & & & & & & & & & & \\
\hline 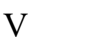 & & & & & & & & & & & & & & & & & & $0.24^{\prime}$ \\
\hline & & & & & & & & & & & & & & & & & & \\
\hline $\mathrm{Zn}$ & 88.8 & 71.5 & 75.2 & 458 & 274 & 177 & 50.1 & 84.0 & 126 & 71.9 & 46.9 & 33.4 & 67.5 & 121 & 297 & 494 & 349 & 29.8 \\
\hline
\end{tabular}

* Suspected outliers according to Tukey's rule.

Table 3. Median concentrations of elements in sampled air $\left(\mathrm{ng} \mathrm{m}^{-3}\right)$ obtained for each element in all samples. Median values of soluble concentrations at $\mathrm{pH}=4.7$ and $T=5^{\circ} \mathrm{C}$ at $t_{\infty}$, median values of total concentrations (individual values reported in Table 2), and median \% of soluble fraction $S$ at $t_{\infty}$ (standard deviations in brackets*) are reported. Total concentrations reported by Benetello et al. (2018) (average annual values) and by Armiento et al. (2013) (range of given values) are also reported here for comparison.

\begin{tabular}{|c|c|c|c|c|c|}
\hline & $\begin{array}{l}\text { Soluble concentration } \\
\left(\mathrm{ng} \mathrm{m}^{-3}\right) \\
\text { (this study) }\end{array}$ & $\begin{array}{l}\text { Total concentration } \\
\left(\mathrm{ng} \mathrm{m}^{-3}\right) \\
\text { (this study) }\end{array}$ & $\begin{array}{l}S_{t=\infty}(\%) \\
\text { (this study) }\end{array}$ & $\begin{array}{l}\text { Total concentration } \\
\left(\mathrm{ng} \mathrm{m}^{-3}\right) \\
\text { Benetello et al. }(2018)\end{array}$ & $\begin{array}{l}\text { Total concentration } \\
\left(\mathrm{ng} \mathrm{m}^{-3}\right) \\
\text { Armiento et al. (2013) }\end{array}$ \\
\hline $\mathrm{Al}$ & 9.68 & 73.6 & $12(66)$ & 273 & \\
\hline As & $<$ LOD & 1.20 & $28(28)$ & 0.5 & $0.33-0.81$ \\
\hline $\mathrm{Ba}$ & 2.99 & 7.79 & $37(55)$ & 12 & \\
\hline $\mathrm{Cd}$ & 0.183 & 0.325 & $62(26)$ & & $0.06-0.38$ \\
\hline $\mathrm{Cr}$ & 1.60 & 4.00 & $26(65)$ & & $1.09-2.75$ \\
\hline $\mathrm{Cu}$ & 3.09 & 19.3 & $22(13)$ & 8 & $8.64-22.47$ \\
\hline $\mathrm{Fe}$ & 38.4 & 354 & $14(15)$ & 150 & 128.9-975.2 \\
\hline K & 661 & 827 & $91(30)$ & 455 & \\
\hline $\mathrm{Mn}$ & 4.24 & 10.8 & $44(13)$ & 6 & \\
\hline Mo & 0.741 & 2.21 & $40(22)$ & & \\
\hline $\mathrm{Pb}$ & 3.19 & 9.89 & $39(30)$ & 9 & $5.57-14.53$ \\
\hline $\mathrm{Rb}$ & 1.58 & 2.05 & 88 (19) & & \\
\hline $\mathrm{Sb}$ & 0.499 & 2.42 & $20(10)$ & 2.2 & \\
\hline $\mathrm{Sr}$ & 0.848 & 1.62 & $41(113)$ & & \\
\hline V & 0.430 & 0.681 & $52(27)$ & 1.2 & \\
\hline W & 0.009 & 0.189 & $15(8)$ & & \\
\hline $\mathrm{Zn}$ & 8.61 & 86.4 & $102(80)$ & 40 & $22.8-60.98$ \\
\hline
\end{tabular}

* standard deviations reflect the high sample-to-sample variability.

from PM to atmospheric aqueous phases is modelled. The fact that a fraction of the elements was released immediately after contact with water may indicate that an aqueous phase processing of the particles had already happened during their atmospheric lifetime either because they were in a deliquescent state or because of the presence of fog. As suggested by Scheinhardt et al. (2013) and Tapparo et al. (2020) this atmospheric aqueous phase processing may be dependent on particle chemical composition so more studies are now needed to investigate the underlying mechanisms of atmospheric processing affecting solubilisation kinetics of metals.

\section{ACKNOWLEDGEMENTS}

The authors thank Alessandra Bindella for her careful experimental work and Mauro Meneghetti for technical 
support. This work was partly funded by the Supporting TAlent in ReSearch@University of Padova STARS-StG MOCAA to CG.

\section{SUPPLEMENTARY MATERIAL}

Supplementary data associated with this article can be found in the online version at http://www.aaqr.org.

\section{REFERENCES}

Armiento, G., Inglessis, M., Tagliani, S.M., Montereali, M.R., Nardi, E., Palleschi, S., Piga, L., Sacco, F., Silvestroni, L. and Gianfagna, A. (2013). A comprehensive approach to the investigation of atmospheric particulate $\mathrm{PM}_{2.5}$ : Preliminary results. Period. Mineral. 82: 199-216. doi: 10.2451/2013PM0012.

Badocco, D., Lavagnini, I., Mondin, A., Tapparo, A. and Pastore, P. (2015). Limit of detection in the presence of instrumental and non-instrumental errors: Study of the possible sources of error and application to the analysis of 41 elements at trace levels by ICP-MS technique. Spectrochim. Acta, Part B 107: 178-184. doi: 10.1016/j.s ab.2015.03.009

Benetello, F., Squizzato, S., Masiol, M., Khan, M.B., Visin, F., Formenton, G. and Pavoni, B. (2018). A procedure to evaluate the factors determining the elemental composition of $\mathrm{PM}_{2.5}$. Case study: The Veneto region (northeastern Italy). Environ. Sci. Pollut. Res. 25: 3823-3839. doi: 10.1007/s11356-017-0759-7.

Berlinger, B., Skogen, U., Meijer, C. and Thomassen, Y. (2019). Workplace exposure to particulate matter, bioaccessible, and non-soluble metal compounds during hot work processes. J. Occup. Environ. Hyg. 16: 378-386. doi: 10.1080/15459624.2019.1594841.

Brito, P.H.F., de, Araújo, R.D.S. and Marinho, G. (2018). Composição química do material particulado atmosférico: Uma revisão de literatura. Holos 4: 62-74. doi: 10.15628/holos.2018.4648.

Catalani, S., Fostinelli, J., Gilberti, M.E., Orlandi, F., Magarini, R., Paganelli, M., Madeo, E. and De Palma, G. (2018). Development of a new sequential extraction procedure of nickel species on workplace airborne particulate matter: Assessing the occupational exposure to carcinogenic metal species. Int. J. Anal. Chem. 2018: 3812795. doi: 10.1155/2018/3812795.

Dedele, A., Miskinyte, A. and Grazuleviciene, R. (2019). The impact of particulate matter on allergy risk among adults: Integrated exposure assessment. Environ. Sci. Pollut. Res. 26: 10070-10082. doi: 10.1007/s11356-01904442-5.

Dehghani, S., Moore, F., Vasiluk, L. and Hale, B.A. (2018). The influence of physicochemical parameters on bioaccessibility-adjusted hazard quotients for copper, lead and zinc in different grain size fractions of urban street dusts and soils. Environ. Geochem. Health 40: 1155-1174. doi: 10.1007/s10653-017-9994-6.

Desboeufs, K.V, Losno, R., Vimeux, F. and Cholbi, S. (1999). The $\mathrm{pH}$-dependent dissolution of wind-transported
Saharan dust. J. Geophys. Res. 104: 21287-21299. doi: 10.1029/1999JD900236.

Desboeufs, K.V., Sofikitis, A., Losno, R., Colin, J.L. and Ausset, P. (2005). Dissolution and solubility of trace metals from natural and anthropogenic aerosol particulate matter. Chemosphere 58: 195-203. doi: 10.1016/j.chemo sphere.2004.02.025.

Du, X., Jiang, S., Zeng, X., Zhang, J., Pan, K., Song, L., Zhou, J., Kan, H., Sun, Q., Zhao, J. and Xie, Y. (2019). Fine particulate matter-induced cardiovascular injury is associated with NLRP3 inflammasome activation in Apo $\mathrm{E}^{-/-}$mice. Ecotoxicol. Environ. Saf. 174: 92-99. doi: 10.1016/j.ecoenv.2019.02.064.

Dufka, M. and Dočekal, B. (2018). Characterization of urban particulate matter by diffusive gradients in thin film technique. J. Anal. Methods Chem. 2018: 9698710. doi: 10.1155/2018/9698710.

Ervens, B. and Volkamer, R. (2010). Glyoxal processing by aerosol multiphase chemistry: Towards a kinetic modeling framework of secondary organic aerosol formation in aqueous particles. Atmos. Chem. Phys. 10: 8219-8244. doi: 10.5194/acp-10-8219-2010.

Field, A., Miles, J. and Field, Z. (2012). 6 Correlation. In Discovering Statistics Using R. SAGE PUBLICATIONS, London, pp. 205-244.

Gao, P., Guo, H., Zhang, Z., Ou, C., Hang, J., Fan, Q., He, C., Wu, B., Feng, Y. and Xing, B. (2018). Bioaccessibility and exposure assessment of trace metals from urban airborne particulate matter $\left(\mathrm{PM}_{10}\right.$ and $\left.\mathrm{PM}_{2.5}\right)$ in simulated digestive fluid. Environ. Pollut. 242: 1669-1677. doi: 10.1016/j.envpol.2018.07.109.

Giorio, C., Tapparo, A., Scapellato, M.L., Carrieri, M., Apostoli, P. and Bartolucci, G.B. (2013). Field comparison of a personal cascade impactor sampler, an optical particle counter and CEN-EU standard methods for $\mathrm{PM}_{10}, \mathrm{PM}_{2.5}$ and $\mathrm{PM}_{1}$ measurement in urban environment. J. Aerosol Sci. 65: 111-120. doi: 10.1016/j.jaerosci.2013.07.013.

Hernández-Pellón, A., Nischkauer, W., Limbeck, A. and Fernández-Olmo, I. (2018). Metal(loid) bioaccessibility and inhalation risk assessment: A comparison between an urban and an industrial area. Environ. Res. 165: 140-149. doi: 10.1016/j.envres.2018.04.014.

Hernández-Pellón, A., Mazón, P. and Fernández-Olmo, I. (2019). Quantification of manganese species in particulate matter collected in an urban area nearby a manganese alloy plant. Atmos. Environ. 205: 46-51. doi: 10.1016/j.atmosenv.2019.02.040.

Hsu, S.C., Lin, F.J. and Jeng, W.L. (2005). Seawater solubility of natural and anthropogenic metals within ambient aerosols collected from Taiwan coastal sites. Atmos. Environ. 39: 3989-4001. doi: 10.1016/j.atmosenv. 2005.03.033.

Huang, H., Jiang, Y., Xu, X. and Cao, X. (2018). In vitro bioaccessibility and health risk assessment of heavy metals in atmospheric particulate matters from three different functional areas of Shanghai, China. Sci. Total Environ. 610-611: 546-554. doi: 10.1016/j.scitotenv.201 7.08.074.

Huang, X., Betha, R., Tan, L.Y. and Balasubramanian, R. 
(2016). Risk assessment of bioaccessible trace elements in smoke haze aerosols versus urban aerosols using simulated lung fluids. Atmos. Environ. 125: 505-511. doi: 10.1016/j.atmosenv.2015.06.034.

Joshi, U.M., Vijayaraghavan, K. and Balasubramanian, R. (2009). Elemental composition of urban street dusts and their dissolution characteristics in various aqueous media. Chemosphere 77: 526-533. doi: 10.1016/j.chemosphere. 2009.07.043.

Kastury, F., Smith, E., Karna, R.R., Scheckel, K.G. and Juhasz, A.L. (2018a). An inhalation-ingestion bioaccessibility assay (IIBA) for the assessment of exposure to metal(loid)s in $\mathrm{PM}_{10}$. Sci. Total Environ. 631-632: 92104. doi: 10.1016/j.scitotenv.2018.02.337

Kastury, F., Smith, E., Karna, R.R., Scheckel, K.G. and Juhasz, A.L. (2018b). Methodological factors influencing inhalation bioaccessibility of metal(loid)s in $\mathrm{PM}_{2.5}$ using simulated lung fluid. Environ. Pollut. 241: 930-937. doi: 10.1016/j.envpol.2018.05.094.

Kaufman, J.A., Wright, J.M., Rice, G., Connolly, N., Bowers, K. and Anixt, J. (2019). Ambient ozone and fine particulate matter exposures and autism spectrum disorder in metropolitan Cincinnati, Ohio. Environ. Res. 171: 218-227. doi: 10.1016/j.envres.2019.01.013.

Kowalska, M., Skrzypek, M., Kowalski, M., Cyrys, J., Ewa, N. and Czech, E. (2019). The relationship between daily concentration of fine particulate matter in ambient air and exacerbation of respiratory diseases in Silesian agglomeration, Poland. Int. J. Environ. Res. Public Health 16: 1131. doi: 10.3390/ijerph16071131.

Lao, X.Q., Guo, C., Chang, L., Bo, Y., Zhang, Z., Chuang, Y.C., Jiang, W.K., Lin, C., Tam, T., Lau, A.K.H., Lin, C.Y. and Chan, T.C. (2019). Long-term exposure to ambient fine particulate matter $\left(\mathrm{PM}_{2.5}\right)$ and incident type 2 diabetes: A longitudinal cohort study. Diabetologia 62: 759-769. doi: 10.1007/s00125-019-4825-1.

Liu, H., Liao, J., Jiang, Y., Zhang, B., Yu, H., Kang, J., Hu, C., Li, Y. and Xu, S. (2019). Maternal exposure to fine particulate matter and the risk of fetal distress. Ecotoxicol. Environ. Saf. 170: 253-258. doi: 10.1016/j.ecoenv.2018. 11.068 .

Liu, L., Urch, B., Szyszkowicz, M., Evans, G., Speck, M., Van Huang, A., Leingartner, K., Shutt, R.H., Pelletier, G., Gold, D.R., Brook, J.R., Godri Pollitt, K. and Silverman, F.S. (2018). Metals and oxidative potential in urban particulate matter influence systemic inflammatory and neural biomarkers: A controlled exposure study. Environ. Int. 121: 1331-1340, doi: 10.1016/j.envint.2018.10.055.

Luo, X., Zhao, Z., Xie, J., Luo, J., Chen, Y., Li, H. and Jin, L. (2019). Pulmonary bioaccessibility of trace metals in $\mathrm{PM}_{2.5}$ from different megacities simulated by lung fluid extraction and DGT method. Chemosphere 218: 915-921. doi: 10.1016/j.chemosphere.2018.11.079.

Maalick, Z., Kühn, T., Korhonen, H., Kokkola, H., Laaksonen, A. and Romakkaniemi, S. (2016). Effect of aerosol concentration and absorbing aerosol on the radiation fog life cycle. Atmos. Environ. 133: 26-33. doi: 10.1016/j.atmosenv.2016.03.018.

Meng, Q., Richmond-Bryant, J., Lu, S.E., Buckley, B., Welsh,
W.J., Whitsel, E.A., Hanna, A., Yeatts, K.B., Warren, J., Herring, A.H. and Xiu, A. (2013). Cardiovascular outcomes and the physical and chemical properties of metal ions found in particulate matter air pollution: A QICAR study. Environ. Health Perspect. 121: 558-564. doi: 10.1289/eh p. 1205793.

Mukhtar, A. and Limbeck, A. (2013). Recent developments in assessment of bio-accessible trace metal fractions in airborne particulate matter: A review. Anal. Chim. Acta 774: 11-25. doi: 10.1016/j.aca.2013.02.008.

Nezis, I., Biskos, G., Eleftheriadis, K. and Kalantzi, O.I. (2019). Particulate matter and health effects in offices - A review. Build. Environ. 156: 62-73. doi: 10.1016/j.builde nv.2019.03.042.

Nie, D., Wu, Y., Chen, M., Liu, H., Zhang, K., Ge, P., Yuan, Y. and Ge, X. (2018). Bioaccessibility and health risk of trace elements in fine particulate matter in different simulated body fluids. Atmos. Environ. 186: 1-8. doi: 10.1016/j.atmosenv.2018.05.024.

Pelfrêne, A. and Douay, F. (2018). Assessment of oral and lung bioaccessibility of $\mathrm{Cd}$ and $\mathrm{Pb}$ from smelter-impacted dust. Environ. Sci. Pollut. Res. 25: 3718-3730. doi: 10.1007/s11356-017-0760-1

Popoola, L.T., Adebanjo, S.A. and Adeoye, B.K. (2018). Assessment of atmospheric particulate matter and heavy metals: a critical review. Int. J. Environ. Sci. Technol. 15: 935-948. doi: 10.1007/s13762-017-1454-4.

Roverso, M., Berté, C., Marco, V., Di Lapolla, A., Badocco, D., Pastore, P., Visentin, S. and Cosmi, E. (2015). The metallome of the human placenta in gestational diabetes mellitus. Metallomics 7: 1146-1154. doi: 10.1039/c5mt0 0050e.

Santibáñez-Andrade, M., Quezada-Maldonado, E.M., OsornioVargas, Á., Sánchez-Pérez, Y. and García-Cuellar, C.M., 2017. Air pollution and genomic instability: The role of particulate matter in lung carcinogenesis. Environ. Pollut. 229: 412-422. doi: 10.1016/j.envpol.2017.06.019.

Scheinhardt, S., Müller, K., Spindler, G. and Herrmann, H. (2013). Complexation of trace metals in size-segregated aerosol particles at nine sites in Germany. Atmos. Environ. 74: 102-109. doi: 10.1016/j.atmosenv.2013.03.023.

Tang, Z., Hu, X., Chen, Y., Qiao, J. and Lian, H. (2019). Assessment of in vitro inhalation bioaccessibility of airborne particle-bound potentially toxic elements collected using quartz and PTFE filter. Atmos. Environ. 196: 118124. doi: 10.1016/j.atmosenv.2018.09.045.

Tapparo, A., Di Marco, V., Badocco, D., D’Aronco, S., Soldà, L., Pastore, P., Mahon, B.M., Kalberer, M. and Giorio, C. (2020). Formation of metal-organic ligand complexes affects solubility of metals in airborne particles at an urban site in the Po valley. Chemosphere 241: 125025. doi: 10.1016/j.chemosphere.2019.125025.

Wiseman, C.L.S., Niu, J., Levesque, C., Chénier, M. and Rasmussen, P.E. (2018). An assessment of the inhalation bioaccessibility of platinum group elements in road dust using a simulated lung fluid. Environ. Pollut. 241: 10091017. doi: 10.1016/j.envpol.2018.06.043.

Xia, L., Zhang, C., Li, D., Yang, L., Sun, W., Cai, S., Meng, Q., Shen, J., Wang, Y. and Xu, M. (2019). Fuel fine 
particulate matter induces ovary dysfunction via metal elements imbalance and steroid biosynthesis signaling pathway inhibition. Environ. Sci. Technol. Lett. 6: 26-33. doi: 10.1021/acs.estlett.8b00625.

Xie, J.J., Yuan, C.G., Shen, Y.W., Xie, J., He, K.Q., Zhu, H.T. and Zhang, K.G. (2019). Bioavailability/speciation of arsenic in atmospheric $\mathrm{PM}_{2.5}$ and their seasonal variation: A case study in Baoding city, China. Ecotoxicol. Environ. Saf. 169: 487-495. doi: 10.1016/j.ecoenv.2018.11.026.

Xing, W., Zhao, Q., Scheckel, K.G., Zheng, L. and Li, L. (2019). Inhalation bioaccessibility of $\mathrm{Cd}, \mathrm{Cu}, \mathrm{Pb}$ and $\mathrm{Zn}$ and speciation of $\mathrm{Pb}$ in particulate matter fractions from areas with different pollution characteristics in Henan Province, China. Ecotoxicol. Environ. Saf. 175: 192-200. doi: 10.1016/j.ecoenv.2019.03.062.
Xue, H., Moyle, A.M., Magee, N., Harrington, J.Y. and Lamb, D. (2006). Experimental studies of droplet evaporation kinetics: Validation of models for binary and ternary aqueous solutions. J. Atmos. Sci. 62: 4310-4326. doi: 10.1175/jas3623.1.

Yang, Yang, Ruan, Z., Wang, X., Yang, Yin, Mason, T.G., Lin, H. and Tian, L. (2019). Short-term and long-term exposures to fine particulate matter constituents and health: A systematic review and meta-analysis. Environ. Pollut. 247: 874-882. doi: 10.1016/j.envpol.2018.12.060.

Received for review, October 6, 2019

Revised, January 9, 2020

Accepted, February 10, 2020 